\section{Effect of Fertilizer Concentration on Growth of Double Impatiens}

\author{
Brian E. Whipker, ${ }^{1}$ Shravan \\ D asoju, ${ }^{2}$ M ichael S. Dosmann, ${ }^{2}$ \\ and J effery K. Iles
}

\section{AdDITIONAL INDEX WORDS. I mpatiens wallerana, flood benches, fertilization}

Summary. Double impatiens (I mpati enswallerana H ook.) 'Blackberry I ce' (variegated-leaf) and 'Purple M agic' (green-leaf) were grown on flood benches and irrigated with 50, 100, 200 , or $300 \mathrm{mg}^{-\mathrm{L}^{-1}}$ (ppm) $\mathrm{N}$ to study the effect of fertility on growth and development. Electrical conductivity (EC) levels at week 9 were similar for both cultivars at each fertilizer rate, except for the $100 \mathrm{mg}^{-\mathrm{L}^{-1} \mathrm{~N}}$ where EC levels of 'B lackberry I ce' were more than double those of 'Purple Magic'. This indicated that the nutrient demands were less for 'B lackberry I ce' and fertilization rates lower than 100 $\mathrm{mg} \cdot \mathrm{L}^{-1} \mathrm{~N}$ would be required. After nine weeks, plants grown with $\mathbf{1 0 0}$ $\mathrm{mg} \cdot \mathrm{L}^{-1} \mathrm{~N}$ had a $22 \%$ larger plant diameter than plants grown with either 50 or $200 \mathrm{mg} \cdot \mathrm{L}^{-1} \mathrm{~N}$. Fertilization rates of $50 \mathrm{mg} \cdot \mathrm{L}^{-1} \mathrm{~N}$ resulted in plants which were covered with a higher percentage of blooms per unit of leaf area, but the plants were smaller. Plant tissue dry weight (leaf, bud, stem, and total) increased to the highest level at $100 \mathrm{mg} \cdot \mathrm{L}^{-1} \mathrm{~N}$, then decreased with further increases in fertilization rate. For maximum shoot growth with flood irrigation, growers should apply 100

Journal paper J-18071 of the Iowa Agriculture and $\mathrm{H}$ ome E conomics Experiment Station, Ames, Project 3345, and supported by $\mathrm{H}$ atch Act and State of I owa funds. This research was funded in part with a grant from the l owa N ursery and $L$ andscape Assoc. Research Corp. and the North Carolina Agricultural Research Service (NCARS), Raleigh. U se of trade names in this publication doesnot imply endorsement by theN CARS of products named nor criticism of similar ones not mentioned. Thanks to Ball Seed Co. for supplying the cuttings and Andrew Schmitz for technical assistance. The cost of publishing this paper was defrayed in part by payment of page charges. U nder postal regulations, this paper therefore must be hereby marked advertise ment solely to indicate this fact.

${ }^{1}$ D epartment of H orticultural Science, Box 7609, N orth Carolina State U niversity, Raleigh, N C 27695-7609.

${ }^{2} \mathrm{D}$ epartment of $\mathrm{H}$ orticulture, I owa State U niversity, Ames, IA 50011-1100. mg: $\mathrm{L}^{-1} \mathbf{N}$ when growing 'Purple $M$ agic' double impatiens and a fertilization rate between $\mathbf{5 0}$ and $\mathbf{1 0 0}$ $\mathrm{mg} \cdot \mathrm{L}^{-1} \mathbf{N}$ for 'Blackberry I ce'.

$P$ roviding the necessary mineral elements in the appropriate concentration is important for optimal growth of ornamental plants. Electrical conductivity (EC) levels increase when there is insufficient leaching during irrigation or too much fertilizer is applied. Symptoms of high EC include slow growth, limited root development and plants that appear stunted (D evittand M orris, 1987; M iller et al., 1981). N ew Guinea impatiens (I mpatienssp. hybrids) display a rippled or wavy leaf surface as symptoms of an excessive fertilization rate ( $\mathrm{H}$ artley, 1995; Judd and Cox, 1992). The authors also have observed rippled or cupped leaves on variegated cultivars of doubleimpatiens(I mpatienswallerana), geraniums (Pelargonium xhortorum L.H. Bailey), and lantana (Lantana camara $L$.) when grown at fertilization rates of 200 to $300 \mathrm{mg} \cdot \mathrm{L}^{-1}$ (ppm) of $\mathrm{N}$ while green-leaved cultivars show no leaf distortion. Thusfertilization requirements for optimal growth of double impatiens may vary by cultivar. The objectives of this study were to determine the effect of increased rates of fertility on plant growth and development of double impatiens and to develop fertilization recommendationsfor growers of those plants.

\section{Material and methods}

Rooted cuttings of double impatienscultivarsB lackberry I ce (variegatedleaf type) and Purple $M$ agic (green-leaf type) were potted into 0.6-L (0.16gal), 10-cm-diameter (4-inch), square pots on $7 \mathrm{Feb}$. 1997. Theroot substrate contained 2 soil : 5 sphagnum peat : 3 perlite (by volume) and was amended with ground dolomitic limestoneto $\mathrm{pH}$ 5.1. Plants were grown under the natural occurring photoperiod (lat. $42{ }^{\circ} \mathrm{N}$ ) with day/ night temperature set points of $24 / 18{ }^{\circ} \mathrm{C}\left(75 / 64{ }^{\circ} \mathrm{F}\right)$. The plants were grown on flood benches and irrigated as needed with Excel 15-5-15 Cal-M ag (Scotts, M arysville, O hio) $(15 \mathrm{~N}-2.1 \mathrm{P}-12.5 \mathrm{~K})$ at a rate of 50,100 , 200 , or $300 \mathrm{mg} \cdot \mathrm{L}^{-1} \mathrm{~N}$. N utrient solutions were replaced every 6 to $7 \mathrm{~d}$.

A completely randomized design of eight treatment combinations (two cultivars $\times$ four fertilizer treatments) 

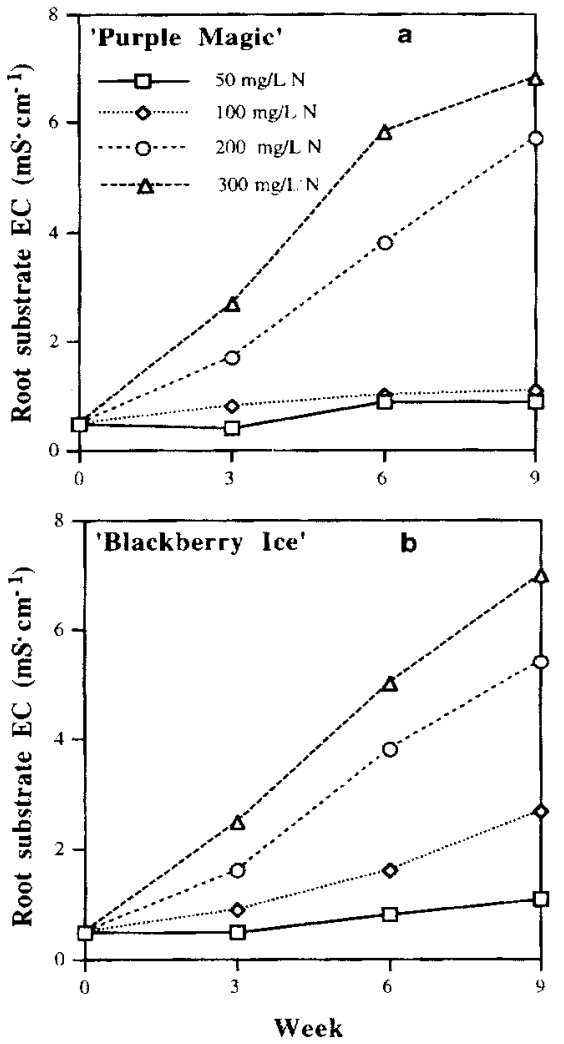

Fig. 1. R oot substrate electrical conductivity (EC) levels of (a) 'Purple Magic' and (b) 'B lackberry I ce' double impatiens fertilized with $50,100,200$, or $300 \mathrm{mg}^{-1} \mathrm{~L}^{-1}(\mathrm{ppm}) \mathrm{N}$ on flood benches. EC levels were significant at $\mathbf{P} \leq \mathbf{0 . 0 0 1}$ and LSD $(\alpha=$ 0.05 ) was $0.39 \mathrm{mS}^{-\mathrm{cm}^{-1}}$ for the fertilizer concentration $\times$ cultivar $\times$ week interaction. Values are means of five replications.

was used. Beginning on 7 Feb. and continuing every 3 weeks until 22 A pr., total plant height measured from the pot rim to the top of the plant and plant diameter (measured at the widest dimension and turned $90^{\circ}$, and averaged) were recorded for five single-plant replications within each treatment. The shoots were destructively harvested and plant fresh weight was also recorded for each replicate. Theroot substratesamples were collected from each replicate by removing the top $2-\mathrm{cm}$ (0.8-inch) layer of substrate and combining the remaining substrate for analysis. The root substrate was analyzed at each sampling datefor $\mathrm{pH}$ (epoxy Ag/ AgCl electrode; Cole-Parmer, Vernon $\mathrm{H}$ ills, III.), EC (Cole-Parmer, Vernon H ills, I II.), $\mathrm{NO}_{3}-$ N (Smith and Scott, 1991) (Q uikC hem $\mathrm{AE}$; L achet, $\mathrm{M}$ ilwaukee, Wis.), $\mathrm{NH}_{4}-\mathrm{N}$ ( $Q$ uikChem $A E$ ), and $P, K, C a$, and $M g$ were determined using an inductively coupled Ar plasma emissions spectro- photometer (IRIS/ AP Duo; Thermo Jarrel Ash, Frankin, M ass.).

LEAF-TISSUE NUTRIENT CONCENTRATION.

Five replicates of each cultivar from each fertilizer rate were sampled for nutrient concentration on 22 Apr. Plants were harvested and divided into leaf, stem and flower portions, dried in a forced-air oven at $67^{\circ} \mathrm{C}\left(153^{\circ} \mathrm{F}\right)$ for $72 \mathrm{~h}$. D ryweight was measured and the tissue ground to pass through a 20-mesh Wiley M ill. Ground leaf tissue samples $(100 \mathrm{mg}$ ) were dry ashed and the dry ash dissolved in $7 \mathrm{~mL}$ aquaregia (J oneset al., 1991) and diluted with distilled water to a volume of $35 \mathrm{~mL}$ for analysis. Concentrations of $\mathrm{P}, \mathrm{K}, \mathrm{Ca}$, $\mathrm{Mg}, \mathrm{B}, \mathrm{Mo}$, and $\mathrm{Zn}$ were determined using an inductively coupled Ar plasma emissions spectrophotometer (IRIS/ AP Duo). Ground leaf tissue samples (100 $\mathrm{mg}$ ) were digested by micro-Kjeldahl (N elson and Sommers, 1980) and analyzed for $\mathrm{N}$ by a $\mathrm{Q}$ uikChem AE (Smith and Scott, 1991).

$D$ ata for the plant tissue and leaf tissue nutrient levels were analyzed using analysis of variance by general linear model procedures(SASI nstitute, Cary, $\mathrm{NC}$ ). M eans were separated by least significant differences (LSD) at $P \leq 0.05$.

Data analysis. Plant dry weight and leaf-tissue nutrient concentration values were regressed using the PRO C REG procedure (SAS Institute, Cary, N.C.) to determine the best fit linear or quadratic model for each element. V ariables in the model were fertilizer concentration (conc) and indicator variables for cultivar (cult), with the full model being as follows:

Concentration $=\beta_{0}+\beta_{1}$ Cult $_{2}+\beta_{2}$ Conc $+\beta_{3}$ Conc $\times$ Cult $+\beta_{4}$ Conc $^{2}+\beta_{5}$ Conc $^{2}$ $\times \mathrm{C}^{3} \mathrm{ult}_{2}$, where Concentration ${ }_{i}=$ fertilizer concentration $(50,100,200$, or $\left.300 \mathrm{mg} \cdot \mathrm{L}^{-1} \mathrm{~N}\right) ; \mathrm{i}=$ variable being re gressed ( N , P, K, Ca, M g, B, M o, Zn, dry weight); Cultivar $_{2}=1$ if cultivar ='Blackberryl ce', 0 otherwise(for 'PurpleM agic'); $\beta_{k}=$ estimated coefficients ( $k=0$ to 5 ).

Termsof themodel werejudged to be significant or nonsignificant and included in the final model based on a comparison of $F$ values at $\alpha=0.05$.

\section{Results and discussion}

Root SUbSTRATE NUTRIENT LEVELS. The root substrate EC levels were significantly different among the fertilizer concentrations and both cultivars over time $(P \leq 0.001)$ with levels increasing as the fertilizer concentration increased (Fig. 1). EC levelsat week 9 weresimilar for both cultivars at each fertilizer rate, except for the $100 \mathrm{mg} \cdot \mathrm{L}^{-1} \mathrm{~N}$ where $\mathrm{EC}$ levels of 'Blackberry Ice' were more than double those of 'Purple Magic'. EC levels for 'Purple $M$ agic' were similar with 50 and $100 \mathrm{mg} \cdot \mathrm{L}^{-1} \mathrm{~N}$, indicating the plants were using the additional nutrients provided at the $100 \mathrm{mg} \cdot \mathrm{L}^{-1} \mathrm{~N}$ rate. The higher EC levels with 100 $\mathrm{mg} \cdot \mathrm{L}^{-1} \mathrm{~N}$ for 'Blackberry Ice' when compared to 'Purple M agic' indicated that cultivar differences in nutrient demands vary and fertilization rates lower than $100 \mathrm{mg} \cdot \mathrm{L}^{-1} \mathrm{~N}$ would be required for 'Blackberry I ce'. Although only one green-leaved and one variegated-leaved cultivar were compared, these results may indicate that nutrient demands of variegated-leaved double impatiens are less than green-leaved cultivars. The increase in EC levels at the fertilization rates $\geq 200 \mathrm{mg} \cdot \mathrm{L}^{-1} \mathrm{~N}$ indicated neither cultivar utilized all of theavailablenutrients and those rates were excessive.
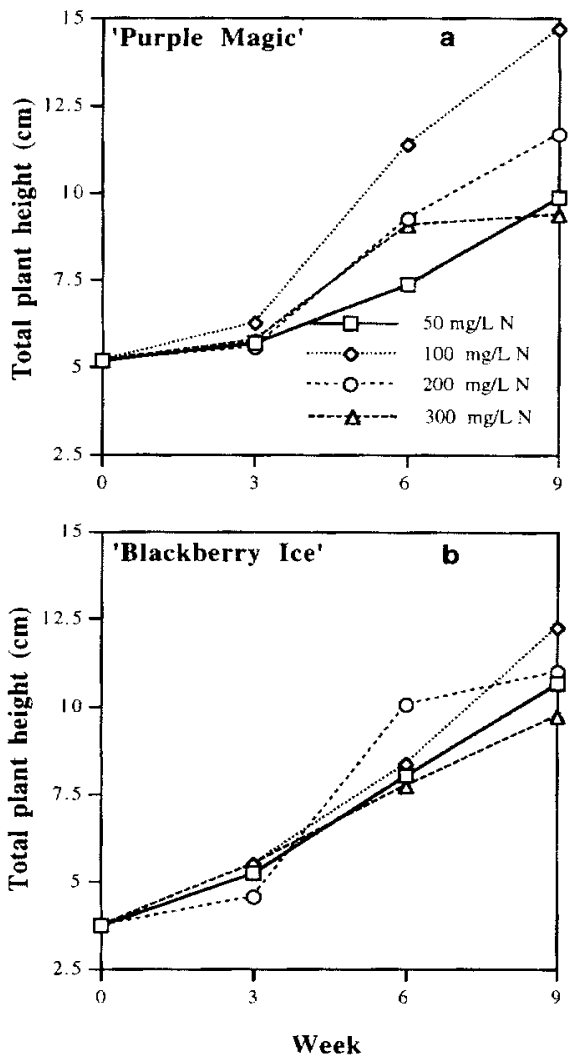

Fig. 2. T otal plant height of (a) 'Purple Magic' and (b) 'Blackberry I ce' double impatiens fertilized with $50,100,200$, or $300 \mathrm{mg} \cdot \mathrm{L}^{-1}(\mathrm{ppm}) \mathrm{N}$ on flood benches. Total plant height was significant at $\mathbf{P} \leq \mathbf{0 . 0 1}$ and LSD ( $\alpha$ $=0.05)$ was $1.18 \mathrm{~cm}$ (0.46 inch) for the fertilizer concentration $\times$ cultivar $x$ week interaction. Values are means of five replications. 


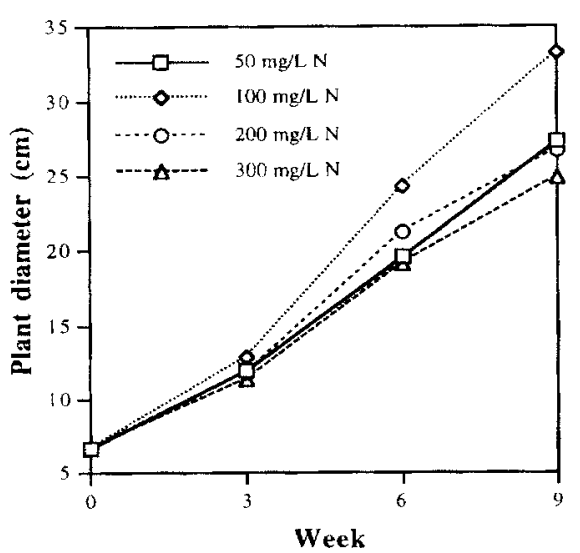

Fig. 3. Plant diameter of double impatiens fertilized with 50, 100, 200, or $300 \mathrm{mg} \cdot \mathrm{L}^{-1}$ (ppm) $\mathrm{N}$ on flood benches. Plant diameter was significant at $\mathbf{P} \leq \mathbf{0 . 0 0 1}$ and LSD $(\alpha=0.05)$ was $1.29 \mathrm{~cm}$ ( 0.5 inch) for the fertilizer concentration $\times$ week interaction. Values (average of both cultivars) are means of $\mathbf{1 0}$ replications.

Similar accumulations of excess fertilizer salts when fertilization rates exceeded the amount required by the plant havebeen reported on $N$ ew $G$ uinea impatiens (Kent and Reed, 1996) and several foliage plant species (Campos and Reed, 1993; Poole and Conover, 1992). L evels of $N$, P , K, C a, and M g in the root substrate also accumulated as the fertilizer concentration increased (data not shown).

Plant Growtr. Total plant heights were significantly different among the fertilizer concentrations and cultivars over time $(P \leq 0.01)$ with $100 \mathrm{mg} \cdot \mathrm{L}^{-1} \mathrm{~N}$ resulting in the tallest plants (Fig. 2). Total plant heights at week nine were similar for both cultivars at each fertilizer rate, except for $100 \mathrm{mg} \cdot \mathrm{L}^{-1} \mathrm{~N}$ where
'Purple M agic' plants were $20 \%$ taller than 'Blackberry I ce'. 'Purple M agic' plants grown with the $200 \mathrm{mg} \cdot \mathrm{L}^{-1} \mathrm{~N}$ were the next tallest plants, while plants grown with 50 or $300 \mathrm{mg} \cdot \mathrm{L}^{-1} \mathrm{~N}$ were the shortest. 'Blackberry Ice' plants grown with 50 or $200 \mathrm{mg} \cdot \mathrm{L}^{-1} \mathrm{~N}$ were similar in height and the shortest plants resulted from $300 \mathrm{mg} \cdot \mathrm{L}^{-1} \mathrm{~N}$.

Plant diameter was significantly affected byfertilizer concentration over time $(P \leq 0.001)$ (Fig. 3). D ifferences in plant diameter occurred only after 6 weeks of growth, with smaller plant growth resulting with 50 or $300 \mathrm{mg}^{-1} \mathrm{~N}$. After 9 weeks, plants grown with $100 \mathrm{mg} \cdot \mathrm{L}^{-1} \mathrm{~N}$ were $22 \%$ larger than plants grown with either 50 or $200 \mathrm{mg} \cdot \mathrm{L}^{-1} \mathrm{~N}$. Fertilization rates of $50 \mathrm{mg} \cdot \mathrm{L}^{-1} \mathrm{~N}$ resulted in plants which werecovered with ahigher percentage of blooms per unit of leaf area (visual observations), but the plantsweresmaller. Similar reductions in plant diameter, due in part to a reduction in leaf size as the $\mathrm{N}$ fertilization rate increased, were reported byKentand Reed (1996) forN ew Guinea impatiens.

There wassignificant quadratic interaction among the fertilizer concentrations and cultivars $(P \leq 0.001)$ for plant tissue dry weight (leaf, bud, stem, and total) (Table 1). 'Purple M agic' plants had a greater dry weight than 'Blackberry I ce' over all the fertilization rates. Plant tissue dry weight (leaf, bud, stem, and total) increased to the highest level at $100 \mathrm{mg} \cdot \mathrm{L}^{-1} \mathrm{~N}$, then decreased as fertilization rate increased. Judd and Cox (1992) reported a similar reduction in New Guinea impatiens dry weight with root substrate EC levels $>1.5 \mathrm{mS} \cdot \mathrm{cm}^{-1}$. The greater dry weight with green plants compared to variegated plants is in agree- ment with Sadof and Raupp (1991) who reported green plants had a higher mean relativegrowth rate, butalower amount of new leaf area per each new unit of plant biomass that accumulated when compared to variegated plants.

LEAF TISSUE NUTRIENT CONCENTRATION. L eaf tissue concentrations of $N, P$, and $K$ exhibited a quadratic interaction among the fertilizer concentrationsand cultivars $(P \leq 0.001)$ (Table 2$)$. L eaf tissue concentrations of $\mathrm{N}, \mathrm{P}$, and $\mathrm{K}$ increased with the fertilization rate, however, levels were higher for 'Blackberry I ce' than 'Purple M agic' over all fertilization rates. $\mathrm{H}$ igher tissue $\mathrm{N}$ concentration was in agreement with Sadof and Raupp (1991) who reported elevated $\mathrm{N}$ in the phloem of variegated plants compared to green plants. Tissue $\mathrm{Ca}$ concentrations were similar for both cultivars and levels decreased as the fertilizer rate increased. The decrease in leaf tissueC aconcentrationsmaybeattributed to theantagonistic relationship between $\mathrm{K}$ and $\mathrm{Ca}$. Competition from increased rates of $K$ has been reported to decrease $\mathrm{Ca}$ content in poinsettias (Euphorbia pulcherrimaWilld.) (Strømmeetal., 1994; Whipker and $\mathrm{H}$ ammer, 1997)

\section{Conclusions}

Fertilization rates of $50 \mathrm{mg} \cdot \mathrm{L}^{-1} \mathrm{~N}$ resulted in plants which were smaller than plants fertilized with $100 \mathrm{mg} \cdot \mathrm{L}^{-1}$ N. Fertilization rates of 200 to 300 $\mathrm{mg} \cdot \mathrm{L}^{-1} \mathrm{~N}$ resulted in an accumulation of fertilizer salts in the root substrate and a reduction in plant growth. For maximum shoot growth, growers should apply $100 \mathrm{mg} \cdot \mathrm{L}^{-1} \mathrm{~N}$ when growing 'Purple $M$ agic' double impatiens on flood benches. Because'Blackberry

Table 1. R egression coefficients of models for plant tissue dry weight of 'Purple Magic' (PM) green-leaf and 'B lackberry I ce' (BI) variegated-leaf double impatiens fertilized with $50,100,200$, or $300 \mathrm{mg}^{-1}$ (ppm) $\mathrm{N}$ on flood benches (28.35 g $=1.0 \mathrm{oz}$ ).

\begin{tabular}{|c|c|c|c|c|}
\hline $\begin{array}{l}\text { Tissue and } \\
\text { cultivar }\end{array}$ & $\begin{array}{l}\text { R egression } \\
\text { equation }\end{array}$ & $\mathbf{R}^{2}$ & $\begin{array}{c}\text { Adjusted } \\
\mathbf{R}^{2}\end{array}$ & $\begin{array}{c}\text { R egression } \\
\text { F statistic }\end{array}$ \\
\hline Leaf $(g)$ & & 0.612 & 0.568 & 13.8 \\
\hline $\mathrm{BI}$ & $y=2.09^{* * *}+0.21(\text { conc })^{* *}-0.000045\left(\text { conc }^{2}\right)^{*}$ & & & \\
\hline Bud $(g)$ & & 0.809 & 0.793 & 50.8 \\
\hline PM & $y=3.14^{* * *}+0.0089(\text { conc })^{*}-0.000038\left(\text { conc }^{2}\right)^{* * *}$ & & & \\
\hline PM & $y=1.17^{* * *}+0.019(\text { conc })^{* * *}-0.00006\left(\text { conc }^{2}\right)^{* * *}$ & & & \\
\hline $\mathrm{BI}$ & $y=1.17^{* * *}+0.0062(\text { conc })^{* * *}-0.000022\left(\text { conc }^{2}\right)^{* * *}$ & & & \\
\hline Total $(\mathrm{g})$ & & 0.727 & 0.704 & 31.9 \\
\hline PM & $y=7.14^{* * *}+0.038(\text { conc })^{* * *}-0.00014\left(\text { conc }^{2}\right)^{* * *}$ & & & \\
\hline $\mathrm{BI}$ & $y=4.64^{* * *}+0.038(\text { conc })^{* * *}-0.00014\left(\text { conc }^{2}\right)^{* * *}$ & & & \\
\hline
\end{tabular}


T able 2. R egression coefficients of models for leaf tissue macro- and micronutrient concentration of 'Purple M agic' (PM) green-leaf and 'B lackberry I ce' (BI) variegated-leaf double impatiens fertilized with $50,100,200$, or $300 \mathrm{mg}^{\cdot \mathrm{L}^{-1}}(\mathrm{ppm}) \mathrm{N}$ on flood benches.

\begin{tabular}{|c|c|c|c|c|}
\hline $\begin{array}{l}\text { Element (\%) } \\
\text { and cultivar }\end{array}$ & $\begin{array}{l}\text { Regression } \\
\text { equation }\end{array}$ & $\mathbf{R}^{2}$ & $\begin{array}{c}\text { Adjusted } \\
\mathbf{R}^{2}\end{array}$ & $\begin{array}{l}\text { Regression } \\
\text { F statistic }\end{array}$ \\
\hline $\begin{array}{l}\text { N (\%) } \\
\mathrm{PM} \\
\mathrm{BI}\end{array}$ & $\begin{array}{l}y=3.57^{* * *}+0.0169(\text { conc })^{* * *}-0.000032\left(\text { conc }^{2}\right)^{* *} \\
y=3.95^{* *}+0.0169(\text { conc })^{* * *}-0.000032\left(\text { conc }^{2}\right)^{* *}\end{array}$ & 0.691 & 0.665 & 26.8 \\
\hline $\begin{array}{l}\mathrm{P}(\%) \\
\mathrm{PM} \\
\mathrm{BI}\end{array}$ & $\begin{array}{l}y=0.133^{*}+0.0046(\text { conc })^{* * *}-0.00001\left(\operatorname{conc}^{2}\right)^{* * *} \\
y=0.133^{*}+0.0069(\text { conc })^{* *}-0.000017\left(\text { conc }^{2}\right)^{* *}\end{array}$ & 0.750 & 0.721 & 26.2 \\
\hline $\begin{array}{l}\mathrm{K}(\%) \\
\mathrm{PM} \\
\mathrm{BI}\end{array}$ & $\begin{array}{l}y=1.01^{* * *}+0.0087(\text { conc })^{* *}-0.00001\left(\text { conc }^{2}\right)^{*} \\
y=1.81^{* * *}+0.0087(\text { conc })^{* *}-0.00001\left(\text { conc }^{2}\right)^{*}\end{array}$ & 0.800 & 0.783 & 48.0 \\
\hline $\begin{array}{l}\text { Ca (\%) } \\
\text { Both cultivars }\end{array}$ & $y=4.34^{* * *}-0.0000046\left(\operatorname{conc}^{2}\right)^{* * *}$ & 0.331 & 0.314 & 18.8 \\
\hline $\begin{array}{l}\mathrm{Mg}(\%) \\
\mathrm{PM} \\
\mathrm{BI}\end{array}$ & $\begin{array}{l}y=0.85^{* * *}+0.001(\text { conc })^{*}-0.000004\left(\text { conc }^{2}\right)^{* *} \\
y=0.754^{* *}+0.001(\text { conc })^{*}-0.000002\left(\text { conc }^{2}\right)^{* *}\end{array}$ & 0.346 & 0.271 & 4.6 \\
\hline $\begin{array}{l}\mathrm{B}\left(\mathrm{mg} \mathrm{L}^{-1}\right) \\
\mathrm{PM} \\
\mathrm{BI}\end{array}$ & $\begin{array}{l}y=54.52^{* * *}+0.35(\text { conc })^{* * *}-0.0006\left(\text { conc }^{2}\right)^{* *} \\
y=64.78^{* * *}+0.35(\text { conc })^{* * *}-0.0006\left(\text { conc }^{2}\right)^{* *}\end{array}$ & 0.738 & 0.717 & 33.9 \\
\hline $\begin{array}{l}\left.\text { Mo }\left(\mathrm{mg}^{-1}\right)^{-1}\right) \\
\text { Both cultivars }\end{array}$ & $y=30.89^{* * *}-0.15(\text { conc })^{* * *}+0.0002\left(\text { conc }^{2}\right)^{*}$ & 0.771 & 0.758 & 62.2 \\
\hline $\begin{array}{l}\mathrm{Zn}\left(\mathrm{mg} \cdot \mathrm{L}^{-1}\right) \\
\quad \mathrm{PM} \\
\mathrm{BI}\end{array}$ & $\begin{array}{l}y=65.53^{* * *}+0.13(\text { conc })^{* *} \\
y=87.51^{* * *}+0.13(\text { conc })^{* *}\end{array}$ & 0.270 & 0.230 & 6.8 \\
\hline
\end{tabular}

$\overline{*, * *, * * *}$ Significant regression equation terms at $\mathrm{P} \leq 0.05,0.01$, or 0.001 , respectively.

I ce' plants have a lower growth rate and higher accumulation of fertilizer salts in the root substrate than 'Purple $M$ agic' plants, fertilization ratesslightly lower than $100 \mathrm{mg} \cdot \mathrm{L}^{-1} \mathrm{~N}$ would be recommended with flood benches. General grower recommendationssuggest applying 33\% to 50\%less fertilizer to flood bench grown plantsthan handwatered plants (Reed, 1996). Therefore, assuming this applies to double impatiens, adjusting the $100 \mathrm{mg} \cdot \mathrm{L}^{-1} \mathrm{~N}$ recommended fertilization rateofflood bench irrigated plants to hand-watering would result in a recommended hand-watering irrigation rate of 150 to $200 \mathrm{mg} \cdot \mathrm{L}^{-1} \mathrm{~N}$, with the lower range suggested for 'Blackberry I ce'.

\section{Literature cited}

Campos, R. and D.W. Reed. 1993. D etermination of constant-feed liquid fertilization rates for Spathiphyllum 'Petite' and D ieffenbachia 'C amille'. J. Environ. H ort. 11:22-24

D evitt, D .A. and R.L. M orris. 1987. M orphological response of flowering annuals to salinity. J. Amer. Soc. H ort. Sci. 112:951-955.

H artley, D.E. 1995. Feeding and watering, p. 31-39. In: W. Banner and $M$. Klopmeyer (eds.). N ew G uineaimpatiensA Ball guide. Ball, Batavia, III.

Jones, Jr., .B., B. Wolf, and H.A. Mills. 1991. Plant analysis handbook. Micromacro Publishing, Athens, Ga.

Judd, L.K. and D.A. Cox. 1992. Growth of New Guinea impatiens inhibited by high growth-medium electrical conductivity. H ortScience 27:1193-1194.

Kent, M.W. and D.W. Reed. 1996. N itrogen nutrition of $\mathrm{New}$ Guinea impatiens 'Barbados' and Spathiphyllum 'Petite' in a subirrigation system. J. Amer. Soc. H ort. Sci. 121:816-819.

Miller, R.O., D.C. Kiplinger, and H.K. Tayama. 1981. Soluble salts: An overview of negative effects. Florists' Rev. 168(4364):10, 26-27.

Nelson, D.W. and L.E. Sommers. 1980. Total nitrogen analysis of soil and plant tissues. Assn. O ffic. Anal. Chem. 63:770778

Poole, R.T. and C.A. Conover. 1992. Fer- tilizer levels and medium affect foliage plant growth in ebb and flow irrigation systems. J. Environ. H ort. 10:81-86.

Reed, D.W. 1996. Closed production systems for containerized crops, p. 221-245. In: D.W. Reed (ed.). Water, media, and nutrition for greenhouse crops. Ball, Batavia, III.

Sadof, C.S. and M.J. Raupp. 1991. Effect of variegation in Euonymusjaponica var. aureus on two phloem feeding insects, U naspis eu onymi (H omoptera: D iaspididae) and A phis fabae (H omoptera: A phididae). Environ. Entomol. 20:83-89.

Smith, K.A. and A. Scott. 1991. Continuous-flower, flow-injection, and discrete analysis, p. 121-139. In: K.A. Smith (ed.). Soil analysis, modern instrumental techniques. 2 nd ed. $M$ arcel D ekker, $N$ ew York.

Strømme, E., A.R. Selmer-OIsen, H.R. Gislerød, and R. M oe. 1994. Cultivar differencesin nutrient absorption and susceptibility to bract necrosis in poinsettia (Euphorbia pulcherrima Willd. ex Klotzsch). Gartenbauwissenschaft 59:6-12.

Whipker, B.E. and P.A. H ammer. 1997. $\mathrm{N}$ utrient uptake in poinsettia during different stages of physiological development. J. Amer. Soc. H ort. Sci. 122:565-573. 